\title{
Weed Management, Training, and Irrigation Practices for Organic Production of Trailing Blackberry: II. Soil and Aboveground Plant Nutrient Concentrations
}

\author{
Emily K. Dixon and Bernadine C. Strik ${ }^{1,2}$ \\ Department of Horticulture, Oregon State University, 4017 Agriculture and \\ Life Sciences Building, Corvallis, OR 97331
}

\section{David R. Bryla}

U.S. Department of Agriculture, Agricultural Research Service, Horticultural Crop Research Unit, 3420 NW Orchard Avenue, Corvallis, OR 97330 Additional index words. drip irrigation, landscape fabric, weed mat, Rubus, organic fertilizer,
tissue nutrient status

\begin{abstract}
Organic production of blackberries is increasing, but there is relatively little known about how production practices affect plant and soil nutrient status. The impact of cultivar (Black Diamond and Marion), weed management (nonweeded, hand-weeded, and weed mat), primocane training time (August and February), and irrigation (throughout the summer and none postharvest) on plant nutrient status and soil pH, organic matter, and nutrients was evaluated from Oct. 2012 to Dec. 2014 in a mature trailing blackberry (Rubus L. subgenus Rubus Watson) production system. The study site was certified organic and machine harvested for the processed market. The planting was irrigated by drip and fertigated with fish hydrolysate and fish emulsion fertilizer. Soil $\mathbf{p H}$, organic matter content, and concentrations of soil nutrients, including ammonium-nitrogen $\left(\mathrm{NH}_{4}-\mathrm{N}\right)$, potassium $(\mathrm{K})$, calcium $(\mathrm{Ca})$, magnesium (Mg), sulfur (S), copper (Cu), manganese (Mn), and zinc (Zn), were greater under weed mat than in hand-weeded plots. Soil $K$ and boron $(B)$ were below recommended standards during the study, despite a high content of $K$ in the fish fertilizer and supplemental $B$ applications. Primocane leaf nutrient concentrations were below the $\mathrm{N}, \mathrm{K}, \mathrm{Ca}$, and $\mathrm{Mg}$ sufficiency standards in 'Black Diamond' and were lower than in 'Marion' for $\mathrm{N}$, phosphorus (P), Ca, $\mathrm{Mg}, \mathrm{S}, \mathrm{B}$, and $\mathrm{Zn}$ in at least one year. In contrast, floricane leaves and fruit tended to have higher nutrient concentrations in 'Black Diamond' than in 'Marion'. Weed management strategy affected many nutrients in the soil, leaves, and fruit. Often, use of weed mat led to the highest concentrations. Withholding irrigation postharvest had limited effects on plant nutrient concentrations. Primocane training time affected the nutrients in each plant part differently depending on year.
\end{abstract}

Organic blackberry (Rubus L. subgenus Rubus, Watson) production is becoming an important niche market in Oregon, where almost $50 \%$ of the U.S. hectarage (organic or conventional) is located [U.S. Department of Agriculture (USDA), 2014]. Oregon primarily grows trailing types used for the processed

Received for publication 29 Oct. 2015. Accepted for publication 10 Dec. 2015.

We appreciate research funding support provided by the Northwest Center for Small Fruits Research, the USDA National Institute of Food and Agriculture (Formula Grant no. OREI 2010-01940; ORE00409), our industry contributors, and the technical assistance provided by Gil Buller and Amanda Vance. From the MS thesis of E.K. Dixon

${ }^{1}$ Professor.

${ }^{2}$ Corresponding author. E-mail: Bernadine.Strik@ oregonstate.edu. floricanes senesce and are removed from the plant. In an annual or every-year production system (Strik and Finn, 2012), primocanes are growing simultaneously with the floricanes and during fruit production. Because of this unique growth habit, the nutrient status of the vegetative and reproductive plant parts may be quite different as plants could be allocating resources independently to the different cane types (Malik et al., 1991; Mohadjer et al., 2001; Naraguma et al., 1999; Whitney, 1982). For example, primocanes primarily acquire nutrients from the soil, so adequate fertilization during primocane growth is important (Malik et al., 1991; Mohadjer et al., 2001; Naraguma et al., 1999; Whitney, 1982). Floricanes, on the other hand, rely on stored nutrients during early fruiting lateral growth and fruit production (Malik et al., 1991; Mohadjer et al., 2001; Naraguma et al., 1999; Whitney, 1982).

Primocanes are typically trained onto a wire trellis to facilitate management and harvest, usually in late summer or late winter (Strik and Finn, 2012). Summer training of the primocanes has been shown to increase light exposure and flower bud initiation and therefore yield in some cases (Bell et al., 1995). However, in other cases, training time did not affect yield or even decreased yield when primocane training in August was followed by a particularly cold winter (Bell et al., 1992; Dixon et al., 2015).

Weed control is one of the most difficult management problems in organic production because there are few Organic Materials Review Institute (OMRI)-listed products and labor for hand-weeding can be expensive. Some blackberry growers allow weeds to grow in the row (B.C. Strik, personal observation), although this has been shown to be detrimental to blackberry plant growth and yield (Dixon et al., 2015; Harkins et al., 2013; Meyers et al., 2014). Weed mat, or porous landscape fabric, has been used successfully to manage weeds in various production systems (Dixon et al., 2015; Harkins et al., 2013; Makus, 2011; Meyers et al., 2014). It is particularly well suited to trailing blackberry because, unlike many other types of caneberry, trailing types only produce canes from the crown of the plant, so only a small hole in the weed mat is needed for the plant.

Withholding irrigation after harvest has been shown to have little effect on blackberry plant growth and fruit production in Oregon, which has a Mediterranean climate with relatively dry summers and continuous summer irrigation is typical (Dixon et al., 2015; U.S. Department of the Interior, 2013). Blackberry can be irrigated by a variety of methods, from drip to overhead sprinklers, depending on the desired market (Strik and Finn, 2012). However, drip irrigation is usually used in organic production systems because it has the potential to decrease weeds outside of the drip zone, reduce disease presence in the canopy, and can be used to apply fertilizers (fertigation). Fertigation has 
been used effectively with OMRI-listed materials in blackberry (Dixon et al., 2015; Fernandez-Salvador et al., 2015a; Harkins et al., 2013).

Soil in the Willamette Valley, where most Oregon blackberries are grown, tends to be sufficient in $\mathrm{P}$, but $\mathrm{N}, \mathrm{K}$, and $\mathrm{B}$ frequently need to be applied to sustain good growth (Hart et al., 2006). Organic fertilizers are often applied for a certain $\mathrm{N}$ rate [55 to $80 \mathrm{~kg} \cdot \mathrm{ha}^{-1}$ for mature blackberry (Hart et al., 2006)], but unlike many conventional fertilizers, they contain varying levels of other macro- and micronutrients. The effect of organic fertilizers on blackberry growth and soil properties was studied by Harkins et al. (2013) during establishment and by Fernandez-Salvador et al. (2015a, 2015b), although effects over a longer time period and combined with other management practices are still unknown.

The objective of this study was to evaluate several production practices (cultivar, weed management, training time, and irrigation) for their effect on the nutrient status of primocane and fruiting lateral leaves, and fruit as well as on soil $\mathrm{pH}$, organic matter, and nutrients in a mature, organic planting of trailing blackberry. The planting was machine harvested for the processed market. Marion and Black Diamond were the cultivars used, along with nonweeded, hand-weeded, and weed mat management strategies, August and February primocane training times, and two irrigation strategies (continuous summer irrigation and no irrigation after fruit harvest).

\section{Materials and Methods}

Study site. The study was conducted at the North Willamette Research and Extension Center in Aurora, OR [lat. $45^{\circ} 16^{\prime} 47^{\prime \prime} \mathrm{N}$, long. $122^{\circ} 45^{\prime} 23^{\prime \prime} \mathrm{W}$; USDA plant hardiness zone $8 \mathrm{~b}$ (U.S. Department of the Interior, 2013); elevation $56 \mathrm{~m}$ ] in 2013 and 2014. The soil type at the site is mapped as a Willamette silt loam (fine-silty, mixed, superactive mesic Pachic Ultic Argixeroll). The field was planted with tissue-cultured plugs in 2010 and was certified organic by Oregon Tilth (Corvallis, OR), a USDA accredited agency, in 2012 during the first year of fruit production. When the planting was approaching maturity in Autumn 2012, the soil $\mathrm{pH}$ was 5.7 and contained $2.8 \%$ organic matter, 0.8 ppm nitrate- $\mathrm{N}\left(\mathrm{NO}_{3}-\mathrm{N}\right), 2.8 \mathrm{ppm}$ ammonium-N $\left(\mathrm{NH}_{4}-\mathrm{N}\right), 419$ ppm P (Bray II), and 234 ppm K. See Harkins et al. (2013, 2014) for detailed information on site preparation and establishment and Dixon et al. planting matured.

Experimental design. Four management treatments were included in this study: cultivar (Marion and Black Diamond), irrigation (postharvest and no postharvest), weed management [nonweeded, hand-weeded, and weed mat (a porous, polyethylene groundcover)], and primocane training time (2015) for details on production once the
(August and February). Treatments were arranged in a split-split-split plot design with five replicates. The main plot factor was cultivar with one row each of Marion and Black Diamond per replicate. The rows were spaced $3 \mathrm{~m}$ apart and split into the two further divided into sub-subplots of the weed management and training time combinations. The sub-subplots consisted of four plants spaced $1.5 \mathrm{~m}$ apart within the row and were separated from adjacent plots by $3.0 \mathrm{~m}$ to allow for clearing of the machine harvester. The in-row and between-row plant spacing was equivalent to a planting density of 2222 plants/ha. Four border plants at the end of each row and a border row on each side completed the planting.

Weed management. In nonweeded plots, weeds were allowed to grow after the first year (2010) and were cut to soil level just before machine harvest (early July) to avoid any interference with the catcher plates; the cut weeds were left in the row. In hand-weeded plots, weeds were removed by hand hoeing on several dates through each growing season. The weed mat treatment plots were covered in a 1.4-m-wide strip of black, woven, polyethylene groundcover (TenCate Protective Fabrics; OBC Northwest Inc., Canby, OR), which was centered on the row and secured using 0.1-m-long nails. According to the manufacturer, the weed mat had a density of $0.11 \mathrm{~kg} \cdot \mathrm{m}^{-2}$ and a water flow rate of $6.8 \mathrm{~L} \cdot \mathrm{h}^{-1}$ per $\mathrm{m}^{2}$. Weeds were removed from the planting hole area and from the seams in the weed mat as required. More information on weed management strategies is provided in Dixon et al. (2015).

Irrigation. Each treatment was irrigated with a single lateral of drip tubing (UNIRAM; Netafim USA, Fresno, CA). The tubing had pressure-compensating emitters $\left(1.9 \mathrm{~L} \cdot \mathrm{h}^{-1}\right.$ in-line) spaced every $0.6 \mathrm{~m}$ and was placed along the ground at the base of the plants under the weed mat, or was attached to a third wire on the steel trellis posts (located $\approx 0.3 \mathrm{~m}$ above the ground) in the nonweeded and the hand-weeded plots. The cultivar, irrigation, and weed management treatment combinations were irrigated

Table 1. Total nutrients applied to mature organic trailing blackberry plants during two growing seasons (2013-14).

\begin{tabular}{|c|c|c|c|c|c|c|c|c|c|c|}
\hline \multirow[b]{2}{*}{ Fertilizer $^{z y}$} & \multicolumn{6}{|c|}{ Macronutrients $\left(\mathrm{kg} \cdot \mathrm{ha}^{-1}\right)$} & \multicolumn{4}{|c|}{ Micronutrients $\left(\mathrm{g} \cdot \mathrm{ha}^{-1}\right)$} \\
\hline & $\mathrm{N}$ & $\mathrm{P}$ & $\mathrm{K}$ & $\mathrm{Ca}$ & $\mathrm{Mg}$ & $\mathrm{Na}$ & B & $\mathrm{Cu}$ & $\mathrm{Mn}$ & $\mathrm{Zn}$ \\
\hline \multicolumn{11}{|l|}{2013} \\
\hline Converted Organics 4-2-1 & 31 & 15 & 18 & 2 & 4 & $<1$ & 9 & 5 & 24 & 61 \\
\hline True Organics $5-1-2$ & 42 & 9 & 13 & $<1$ & 3 & 32 & 8 & 2 & 17 & 50 \\
\hline Solubor & - & - & - & - & - & - & 2,200 & - & - & - \\
\hline Pro-Pell-It lime & - & - & - & 762 & - & - & - & - & - & - \\
\hline Pro-Pell-It dolomite & - & - & - & 112 & 58 & - & - & - & - & - \\
\hline \multicolumn{11}{|l|}{2014} \\
\hline True Organics $5-1-2$ & 90 & 10 & 40 & $<1$ & 2 & 28 & 10 & 2 & 25 & 32 \\
\hline Solubor & - & - & - & - & - & - & 2,200 & - & - & - \\
\hline $\mathrm{Nu}-\mathrm{Cop} 50$ & - & - & - & - & - & - & - & 4,400 & - & - \\
\hline
\end{tabular}

${ }^{\mathrm{z}}$ Analyzed by Brookside Laboratories, Inc. (New Bremen, OH). Values for Solubor, Pro-Pell-It lime and dolomite, and $\mathrm{Nu}$-Cop 50 were obtained from the product label.

${ }^{y}$ The two products were fish derivatives mixed 1:3 (v/v) with water before application by fertigation through the drip system and were injected in four equal applications at a rate of $90 \mathrm{~kg} \cdot \mathrm{ha}^{-1}$ total $\mathrm{N}$ (based on percentage of $\mathrm{N}$ as stated on the label) per year.

independently using a manifold with electric solenoid valves and an automatic timer.

Irrigation was scheduled weekly based on estimates of crop evapotranspiration but was adjusted as needed each week to maintain similar leaf water potentials among treat(Dixon et al., 2015). Irrigation was applied from 9 May to 8 Oct. 2012, 17 May to 27 Sept. 2013, and 28 May to 23 Sept. 2014 in . was initiated on the same dates but was July 2012, 19 July 2013, and 15 July 2014 tive water after harvest unil the rainy season began on 12 Oct. 2012, 21 Sept. 2013, and 23 Sept. 2014.

Fertilization. An OMRI-approved fish hydrolysate and fish emulsion blend were diluted 1:3 (v/v) with water and applied through the drip system using a combination of a water-driven pump fertilizer injector (Mix-Rite 571 CW; DEMA, St. Louis, MO) and an electric, low-volume chemigation Inc., Yuma, CO). Although only one injector was needed, the electric pump was installed to reduce injection time $(\approx 1.5 \mathrm{~h}$ per application compared with $\approx 4.5 \mathrm{~h}$ per application with the water-driven pump). The fertilizer was split into eight equal applications (about every 2 weeks from 5 Apr. to 12 July 2013 a total rate of $90 \mathrm{~kg} \cdot \mathrm{ha}^{-1} \mathrm{~N}$ per year (based on percentage of $\mathrm{N}$ as stated on the label). Converted Organics 421 (4N-2P-1K; Converted Organics of California LLC, Gonzales, 2013, and True Organics 512 (5N-0.4P-1.7K; True Organic Products Inc., Spreckels, CA) was used for the last four applications in 2013 and all applications in 2014. Irrigation was run the system injection to flush the drip lines. The fertilizers applied were analyzed for total nutrient content (Brookside Laboratories, New Bremen, $\mathrm{OH}$ ), and the rate of all macro- and micronutrients applied was calculated (Table 1).

Additional granular fertilizers were applied in 2013 and 2014, based on results from irrigation treatments as subplots, which were withheld after the last fruit harvest on 30 


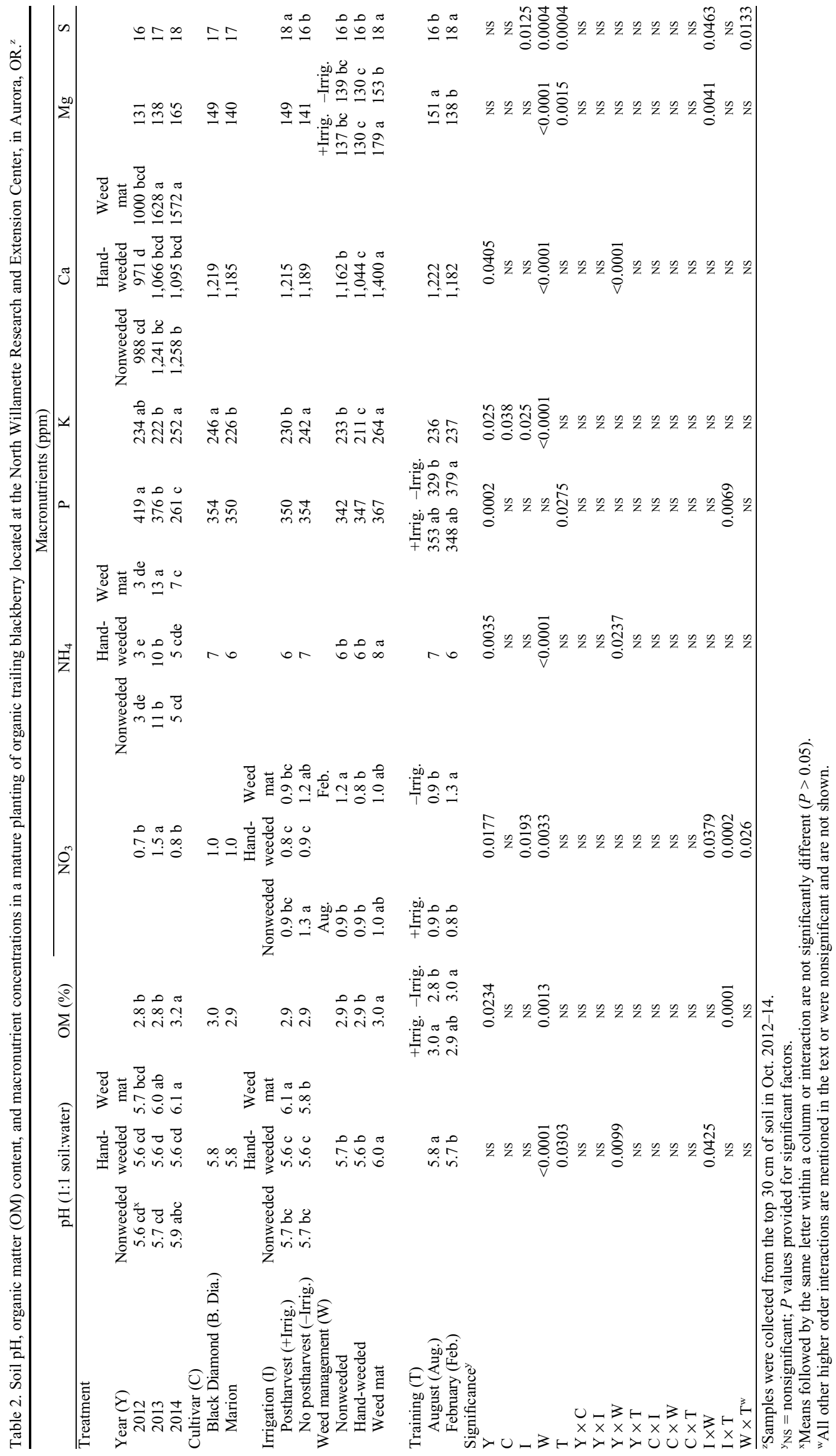



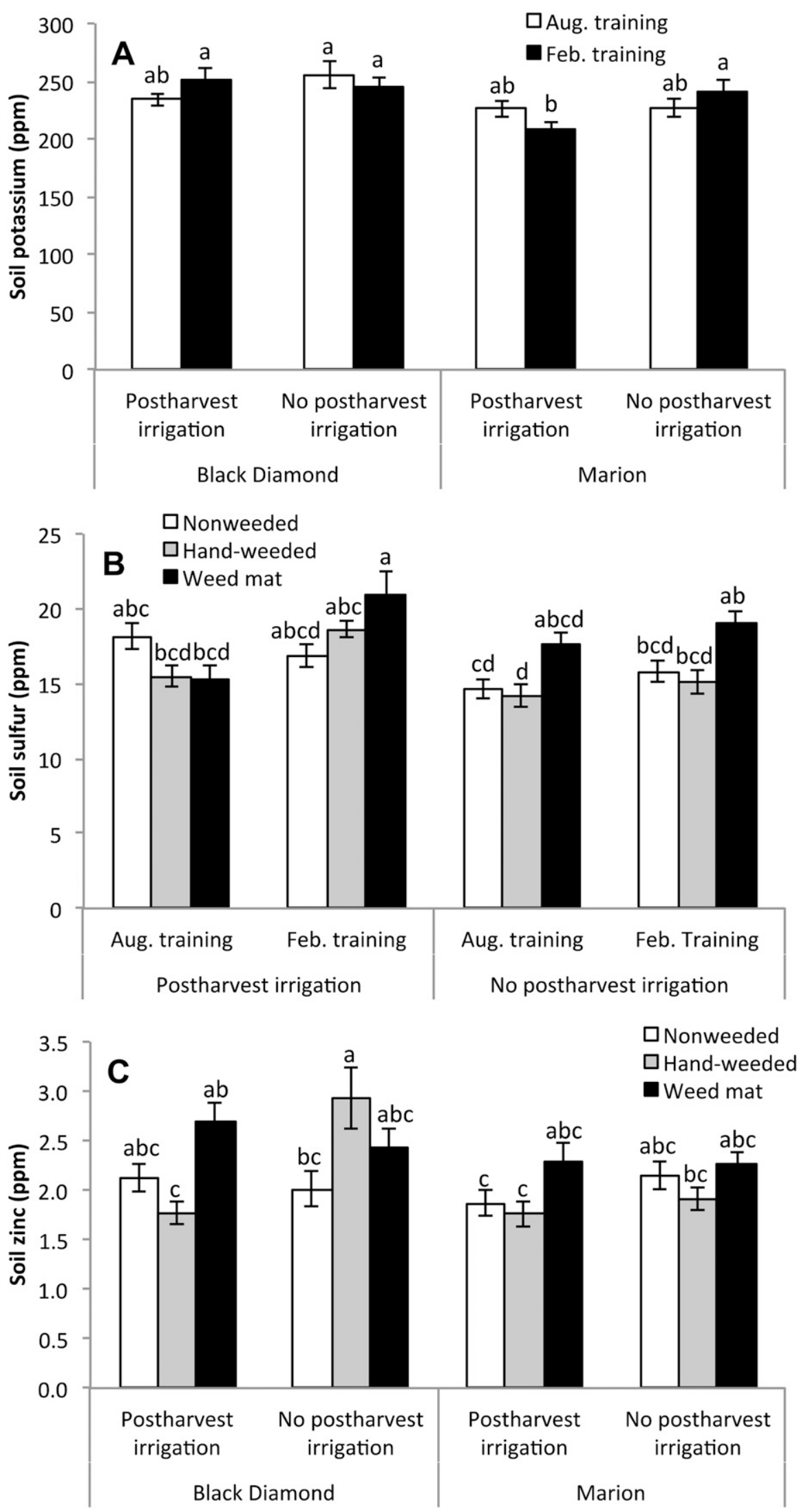

Fig. 1. Soil concentrations of (A) potassium, $(\mathbf{B})$ sulfur, and $(\mathbf{C})$ zinc in a mature planting of organic trailing blackberry located at the North Willamette Research and Extension Center in Aurora, OR. Potassium was significantly affected by a three-way interaction among cultivar, irrigation, and trailing time $(P=0.0031)$. Sulfur was significantly affected by a three-way interaction among irrigation, weed management, and training $(P=0.0213)$. Zinc was significantly affected by a three-way interaction among cultivar, irrigation, and weed management $(P=0.0086)$. Each bar represents the mean $( \pm 1 \mathrm{sE})$ of 3 years. Bars with the same letter within a given interaction are not significantly different $(P>0.05)$. soil and primocane leaf tissue analyses. They included Pro-Pell-It lime and dolomite (Marion Ag Service Inc., Aurora, OR), which was applied in 2013 to increase soil $\mathrm{pH}$, and solubor (U.S. Borax Inc., Valencia, CA), which was applied both years to increase the concentration of $\mathrm{B}$ in the plants. The fertilizer was broadcast over the weed mat. Lime sulfur (Or-Cal Inc., Junction City, OR) was also applied to plants in the spring of both years to control for septoria leaf spot (Septoria rubi Westend) and copper $(\mathrm{Cu} ; \mathrm{Nu}-$ Cop 50 DF; Albaugh Inc., Ankeny, IA) was applied in 2014 to control for purple blotch [Septocyta ruborum (Lib.) Petr.] and cane rust [Kuehneola uredines (Link) Arthur].

Primocane training. Primocanes were trained as they grew along the lower trellis wire used for the drip lines. In the Augusttrained treatment, primocanes were trained to the upper trellis wires on 13-14 Aug. 2012, 27-29 Aug. 2013, and 14 Aug. 2014 using the method described by Dixon et al. (2015). In the February-trained treatment, primocanes were left on the lower trellis wire until they were wrapped and tied to the upper two trellis wires on 21-25 Feb. 2013 and 21-28 Feb. 2014. Primocane training was done by replicate to avoid any possible date effects within treatment over the days required to wrap and tie the canes.

Data collection. Soil was analyzed to evaluate treatment effects over time. Soil samples were collected on 23 Oct. 2012 and 2013, and 27 Oct. 2014. Samples were aggregates of two soil cores taken per plot. The cores were collected using a $2.4-\mathrm{cm}$ diameter, 0.5-m long, slotted, open-side, chrome-plated steel probe (Soil Sampler Model Hoffer; JBK Manufacturing, Dayton, $\mathrm{OH})$. The probe was inserted $0.3 \mathrm{~m}$ deep at a distance of $0.3 \mathrm{~m}$ from the crown in the middle of the row of two different plants in each plot. Soil samples were shipped to Brookside Laboratories for analysis of $\mathrm{pH}$ using the 1:1 soil:water method (McLean, 1982), organic matter using loss on ignition at $360{ }^{\circ} \mathrm{C}$ (Nelson and Sommers, 1996), $\mathrm{NO}_{3}-\mathrm{N}$ and $\mathrm{NH}_{4}-\mathrm{N}$ using automated colorimetric methods after extraction with $1 \mathrm{~m} \mathrm{KCl}$ (Dahnke, 1990), Bray II P, and K, $\mathrm{Ca}, \mathrm{Mg}, \mathrm{S}$, sodium $(\mathrm{Na})$, iron $(\mathrm{Fe}), \mathrm{B}, \mathrm{Cu}$, $\mathrm{Mn}, \mathrm{Zn}$, and aluminum (Al) using inductively coupled plasma (ICP) after extraction of the nutrients using the Mehlich 3 method (Mehlich, 1984)

Leaf samples were collected from the primocanes on 26 July 2013 and 25 July 2014 per standard recommendations for tissue analysis (Hart et al., 2006) and from the floricanes (choosing leaves on the fruiting laterals) on 20 June 2013 and 19 June 2014 (first black fruit stage). Ten recent fully expanded leaves were collected from each plot on each sample date. The leaf samples were analyzed for macro- and micronutrient concentration by Brookside Laboratories. Total $\mathrm{N}$ content was determined in each sample using a combustion analyzer, and $\mathrm{P}$, $\mathrm{K}, \mathrm{Ca}, \mathrm{Mg}, \mathrm{S}, \mathrm{Fe}, \mathrm{B}, \mathrm{Cu}, \mathrm{Mn}, \mathrm{Zn}$, and $\mathrm{Al}$ were determined using an ICP spectrophotometer 
Table 3. Soil micronutrient concentrations in a mature planting of organic trailing blackberry located at the North Willamette Research and Extension Center in Aurora, OR. ${ }^{\mathrm{r}}$

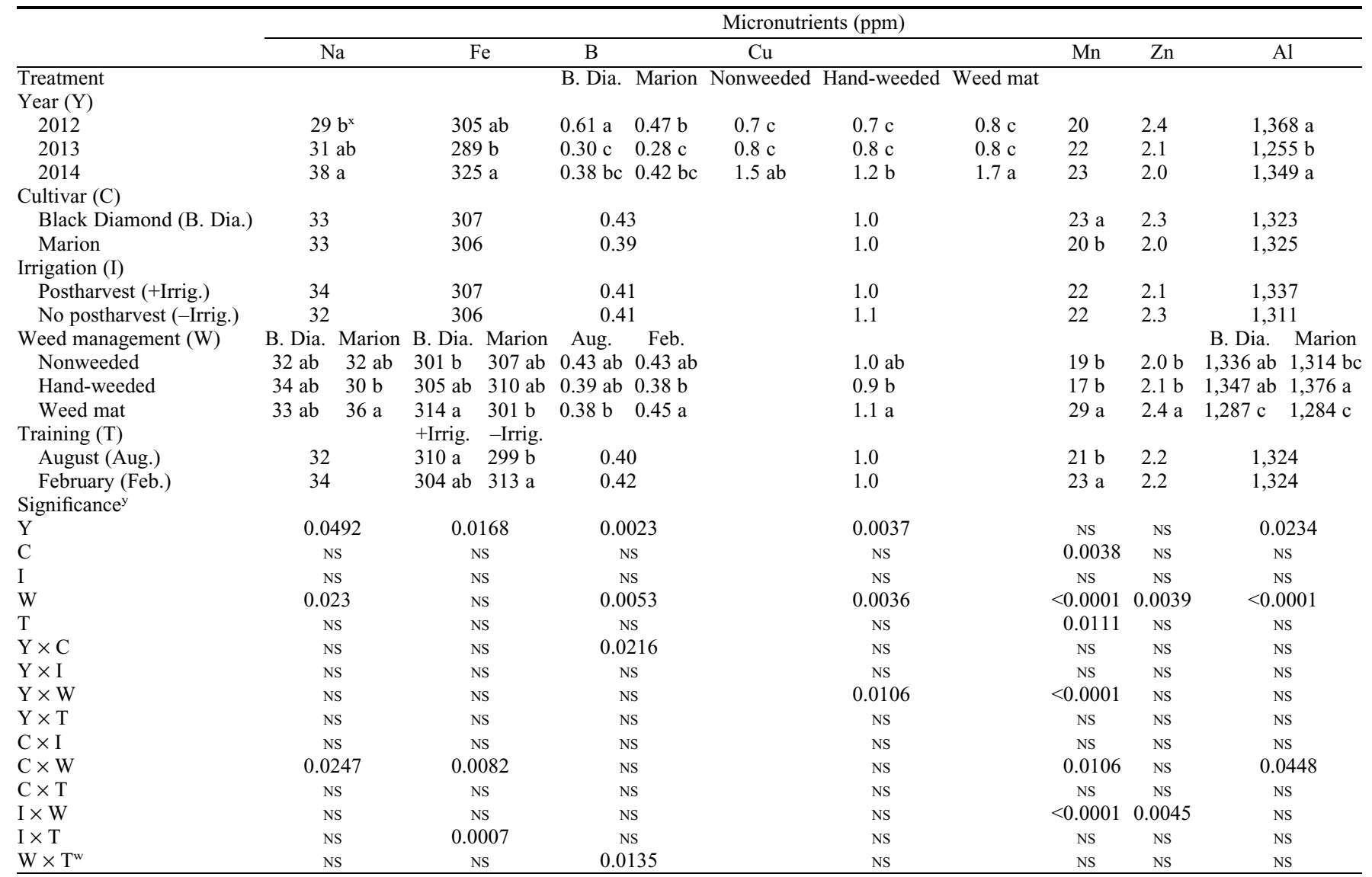

${ }^{\mathrm{z}}$ Samples were collected from the top $30 \mathrm{~cm}$ of soil in Oct. 2012-14.

${ }_{\mathrm{NS}}^{\mathrm{N}}=$ nonsignificant; $P$ values provided for significant factors.

${ }^{\mathrm{x}}$ Means followed by the same letter within a column or interaction are not significantly different $(P>0.05)$.

${ }^{\text {w}}$ All other higher order interactions are mentioned in the text or were nonsignificant and are not shown.

after wet ashing the samples in nitric/ perchloric acid (Gavlak et al., 1994).

Ripe fruit were harvested twice weekly from 24 June to 18 July in both years, using an over-the-row rotary harvester (Littau Harvesters Inc., Stayton, OR). 'Black Diamond' was harvested on every date in both years, whereas 'Marion' was not harvested on the first or last date in either year. A 25-berry subsample per treatment plot was shipped overnight to Brookside Laboratories on 8 July 2013 and 7 July 2014 and analyzed for macro- and micronutrient concentration, as described previously.

Floricanes and primocanes were also collected and analyzed for nutrients in the course of the study, and the results were presented by Dixon (2015). Primocane tissue samples were collected in late winter during the dormant period, whereas floricane tissue samples were collected during floricane removal in late summer (August).

Data analysis. Plant nutrient data were analyzed by year because of large differences in weather and to winter damage observed in Dec. 2013 (Dixon et al., 2015). Soil data were analyzed across years to examine treatment effects over time. Within year, data were analyzed by analysis of variance for a split-split-split plot design with cultivar as the main plot factor, postharvest irrigation as the subplot factor, and weed management and training time as subsubplots, using PROC MIXED in SAS (version 9.3; SAS Institute Inc., Cary, NC). The soil data were analyzed using a splitsplit-split-split plot design as above except year was the highest order factor. Residuals were plotted to assess homogeneity of variance (residual by fitted value plot) and normality (histogram of the residuals). When strong fanning was seen in the residual plots, the data were log transformed for analysis to improve homogeneity of variance and to assess proportional effects. Data were back transformed for presentation. Means were compared for treatment effects using Tukey's honestly significant difference test with $\alpha=0.05$. Mean comparisons within significant interactions were done for treatments using least square means with $\alpha=0.05$.

\section{Results}

Soil conditions. Soil pH, organic matter content, and macronutrient concentrations were mainly affected by sample year and weed management strategy (Table 2). Soil organic matter increased in the last year of the study. Soil $\mathrm{NO}_{3}-\mathrm{N}$ and $\mathrm{NH}_{4}-\mathrm{N}$ were higher in 2013 than in 2012 and 2014. Soil K was greater in 2014 than in 2013. Soil P decreased each year from 2012 to 2014. Soil $\mathrm{pH}$ increased over the study period, but only with weed mat. The effects of weed management strategy on soil macronutrients were mixed. In general, soil under the weed mat had the highest $\mathrm{pH}$, organic matter content, and concentration of several macronutrients, including $\mathrm{NH}_{4}-\mathrm{N}, \mathrm{K}, \mathrm{Ca}, \mathrm{Mg}$, and $\mathrm{S}$. The hand-weeded treatment had lower concentrations of several soil macronutrients than the nonweeded treatment, including soil $\mathrm{NO}_{3}-\mathrm{N}$ (in February-trained plots only), $\mathrm{K}$, and $\mathrm{Ca}$.

Cultivar had a limited effect on soil macronutrient concentration. Irrigation affected most soil macronutrients, although mostly through interactions with other treatments. For example, 'Marion' plots that were trained in February had a lower concentration of soil $\mathrm{K}$ when they were irrigated after harvest than when they were not $(P=0.0031$; Fig. 1A). August-trained plots had higher soil $\mathrm{pH}$ and $\mathrm{Mg}$ than Februarytrained plots, whereas February-trained 

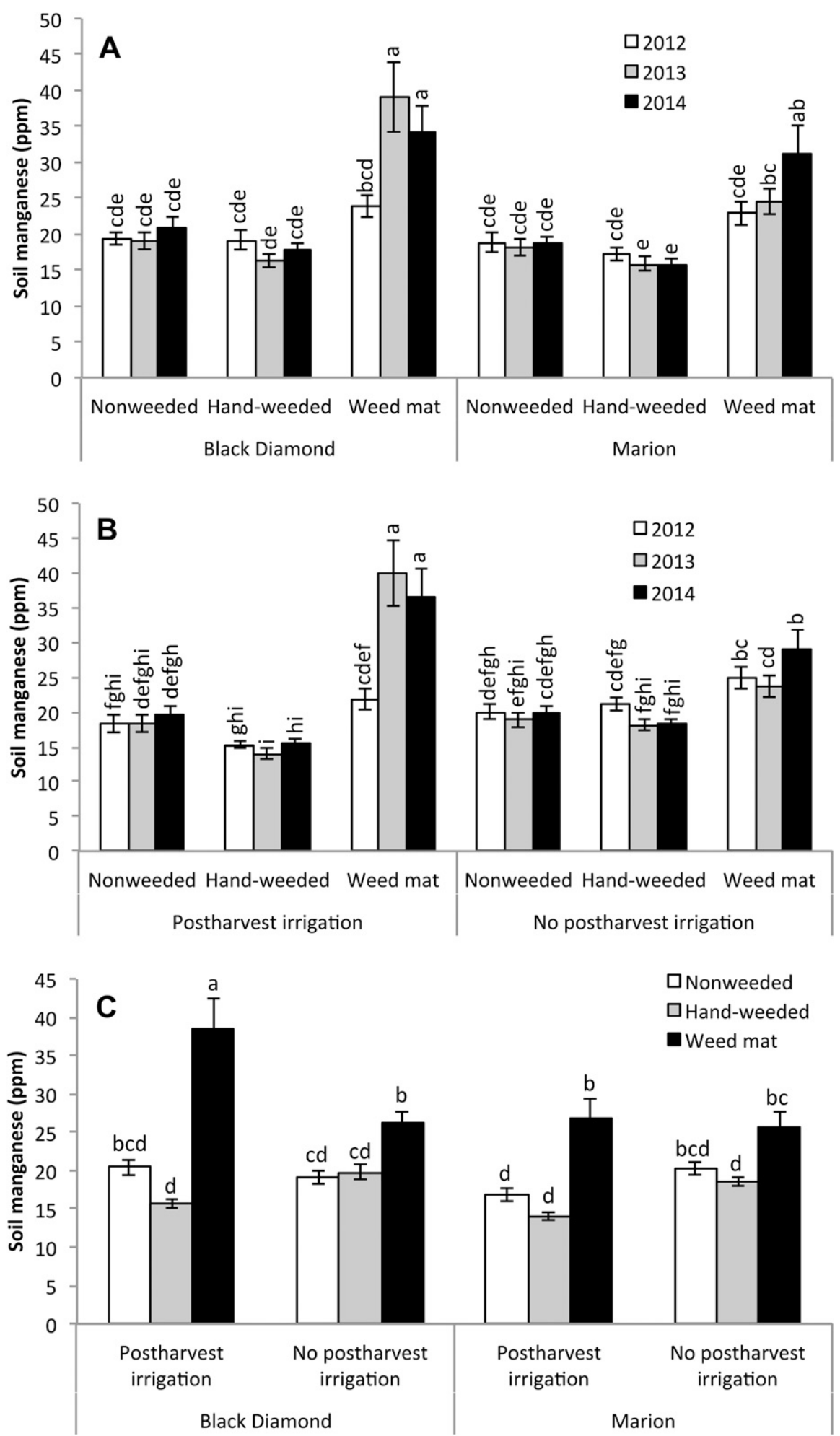

Fig. 2. Soil manganese concentration in mature organic 'Black Diamond' and 'Marion' trailing blackberry as affected by (A) weed management strategy and sample year $(P=0.0041)$, each bar represents the mean $( \pm 1 \mathrm{SE})$; (B) irrigation strategy, weed management strategy, and sample year $(P=0.0006)$, each bar represents the mean $( \pm 1 \mathrm{SE})$ of the two cultivars; and $(\mathbf{C})$ weed management and irrigation strategies $(P=0.0145)$, each bar represents the mean $( \pm 1 \mathrm{SE})$ of 3 years. Mean $\pm \mathrm{SE}$; means followed by the same letter within a given interaction are not significantly different $(P>0.05)$.

plots had higher $\mathrm{NO}_{3}-\mathrm{N}, \mathrm{P}$, and $\mathrm{S}$ in some treatment combinations $(P=0.0213$; Table 2; Fig. 1B).

The concentration of soil micronutrients such as $\mathrm{Na}, \mathrm{Fe}$, and $\mathrm{Cu}$ tended to increase during the study period, whereas soil B decreased over time, and soil $\mathrm{Zn}$ and $\mathrm{Mn}$ were unaffected by year (Table 3 ). Soil B was higher in 'Black Diamond' plots than in 'Marion' plots, but only in 2012. 'Black
Diamond' plots also had higher soil $\mathrm{Fe}$ than 'Marion', but only when weed mat was used. 'Black Diamond' plots irrigated after harvest had higher soil $\mathrm{Zn}$ with weed mat than when hand-weeded, whereas plots that received no postharvest irrigation had higher $\mathrm{Zn}$ with hand-weeding than no weeding $(P=$ 0.0086; Fig. 1C). Soil Zn in 'Marion' plots was unaffected by irrigation or weed management. Soil $\mathrm{Cu}$ was lowest in handweeded plots, whereas weed mat plots had higher soil $\mathrm{Mn}$ and $\mathrm{Zn}$ than the other weed management strategies. Soil under weed mat in 'Black Diamond' plots was especially high in Mn in 2013 and 2014, but in 'Marion', it was only higher in 2014 than in $2012(P=0.0041$; Fig. 2A). A similar pattern was seen under weed mat in the different irrigation treatments $(P=0.0006$; Fig. 2B). In both cultivars, soil Mn was higher in weed mat than in nonweeded or hand-weeded plots when the plots were irrigated after harvest; however, when plots were not irrigated after harvest, those with weed mat had higher soil Mn than other weed management treatments in 'Black Diamond', but were only higher than handweeded in 'Marion' ( $P=0.0145$; Fig. 2C). In plants receiving no irrigation postharvest, soil Fe was higher with February training than when trained in August (Table 3).

Primocane leaf nutrient concentration. 'Marion' had higher concentrations of $\mathrm{N}$, $\mathrm{P}, \mathrm{S}$, and $\mathrm{Zn}$ in the primocane leaves than 'Black Diamond' in 2013 (Table 4), as well as higher concentrations of $\mathrm{Ca}, \mathrm{Mg}$, and $\mathrm{B}$ the following year (Table 5). 'Black Diamond', on the other hand, only had a higher concentration of $\mathrm{Fe}$ and $\mathrm{Al}$ in the primocane leaves and only in 2013. The concentration of many of the nutrients in the primocane leaves of 'Black Diamond' were near the bottom of or below the recommended leaf tissue standards for caneberry in Oregon (Hart et al., 2006). For example, N, K, Ca, $\mathrm{Mg}$, and $\mathrm{B}$ were below the standards in at least one year and $\mathrm{P}$ dropped to the very bottom of the sufficiency range in 2014 'Marion' had leaf B concentrations below the sufficiency range in 2013.

The irrigation treatments had no direct effect on primocane leaf nutrient concentrations in 2013, but in 2014, plots with postharvest irrigation resulted in higher primocane leaf $\mathrm{Fe}$ and $\mathrm{Al}$ than those without (Tables 4 and 5). In 2013, plots with weed control (i.e., hand-weeding or weed mat) had higher primocane leaf $\mathrm{S}$ than nonweeded plots. Plots with weed mat had higher leaf $\% \mathrm{~K}$ than nonweeded plots in 2013 within training time. Plots without postharvest irrigation had higher leaf $\% \mathrm{Mg}$ when nonweeded than with weed mat in 2013. Use of weed mat as a mulch led to higher primocane leaf $\mathrm{Cu}$ and $\mathrm{Zn}$ and lower $\mathrm{Fe}$ and $\mathrm{Al}$ than found with the other weed management treatments. In 2014, the handweeded plots had the highest primocane leaf $\mathrm{Fe}$ and $\mathrm{Al}$ compared with the other weed management treatments, whereas the nonweeded plots had higher primocane leaf 


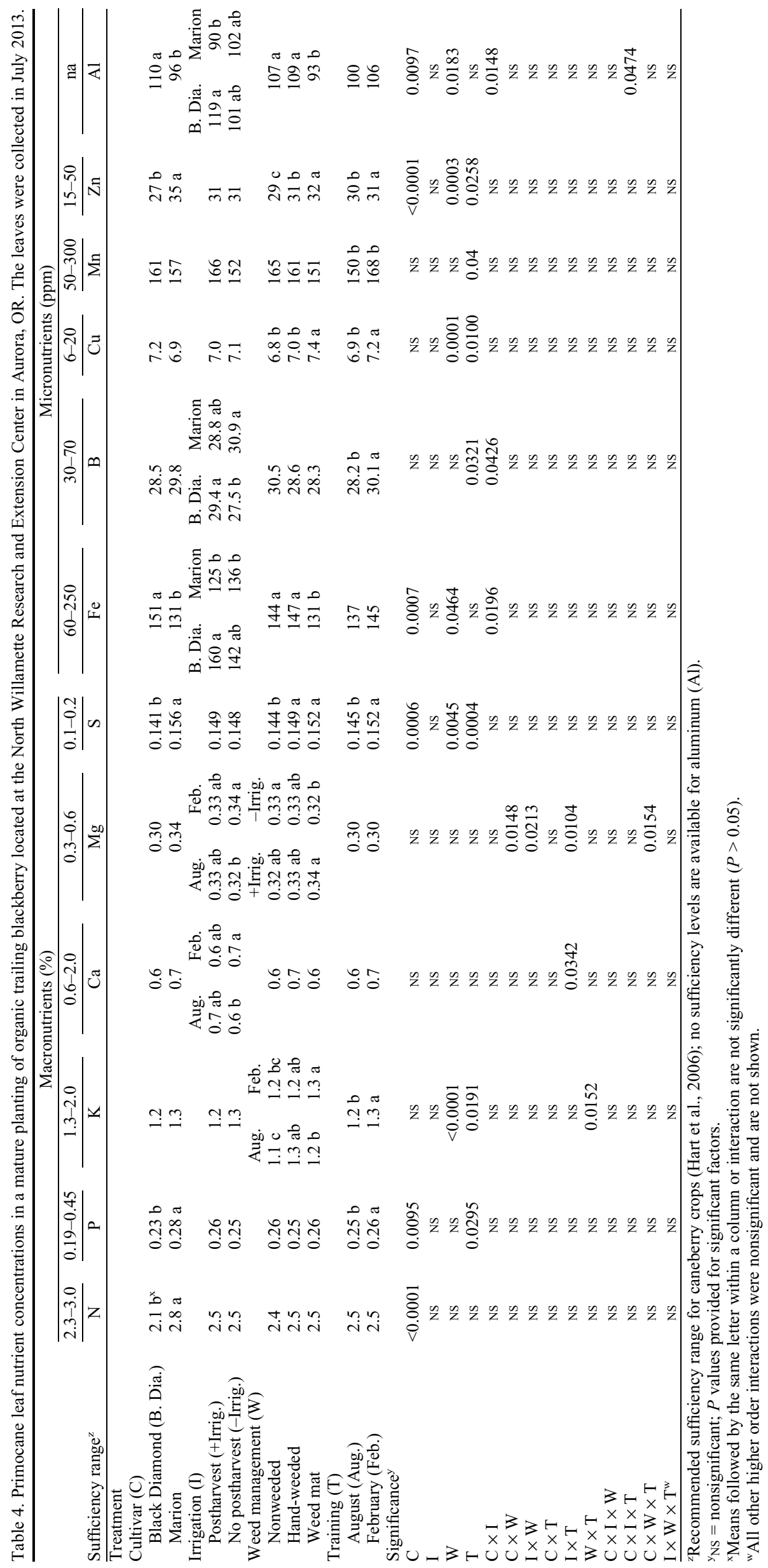




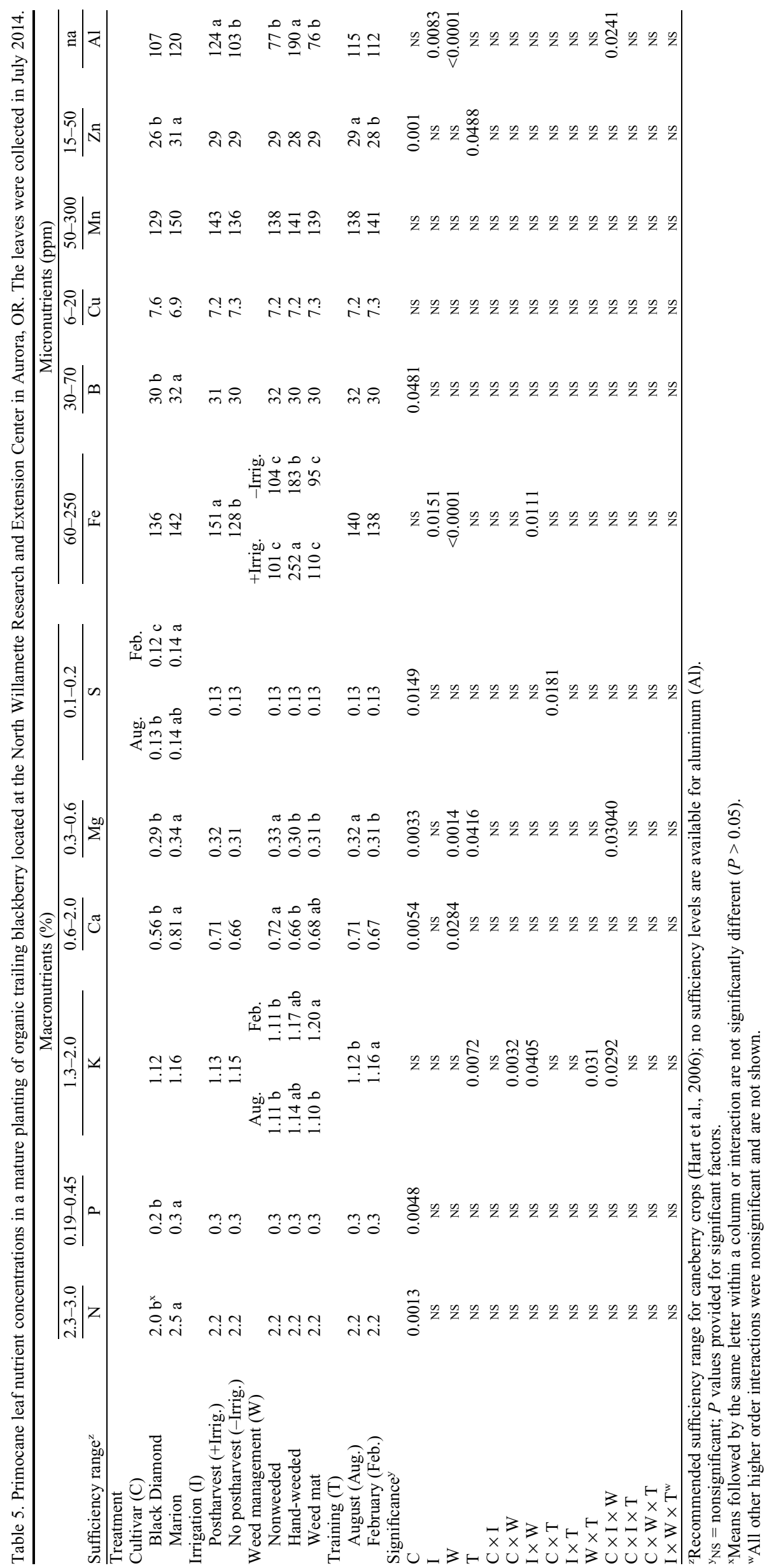




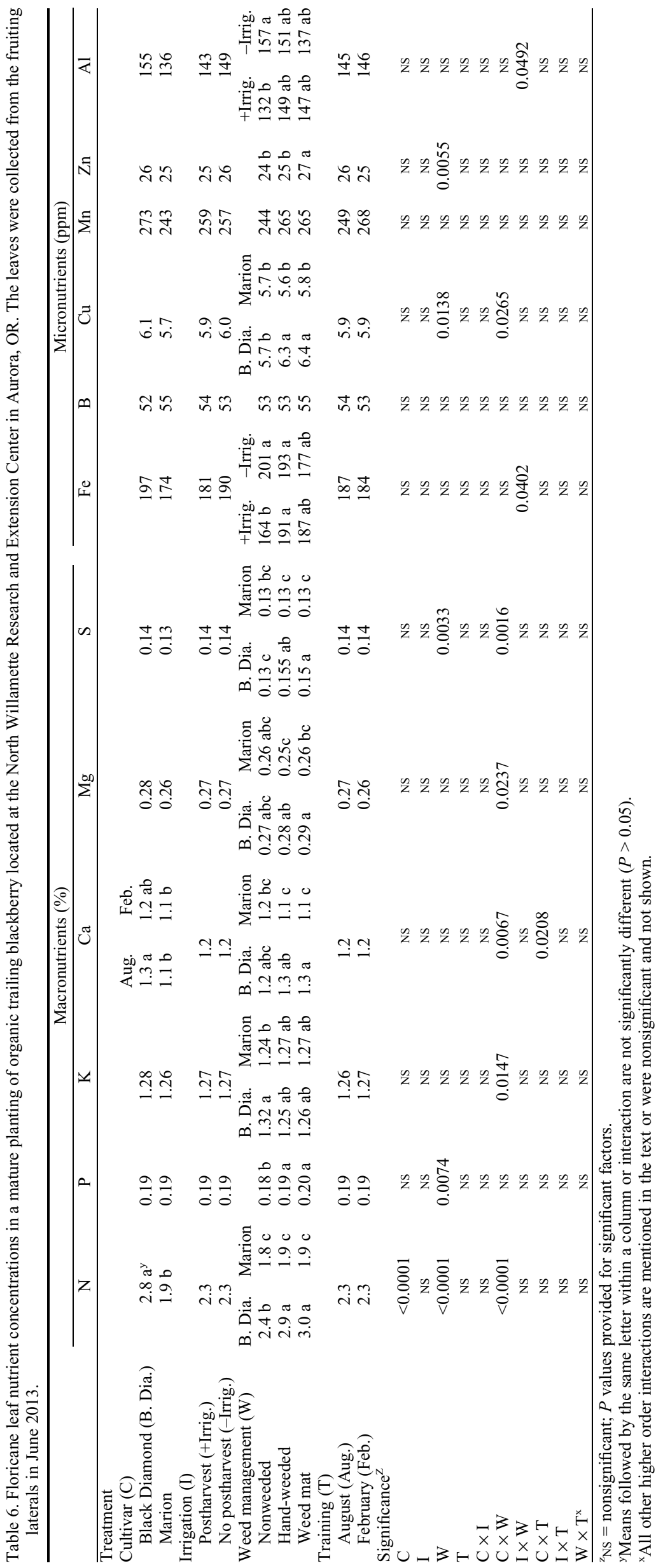

$\mathrm{Ca}$ than hand-weeded plots, and higher primocane leaf $\mathrm{Mg}$ than the plots with either method of weed control.

As far as primocane training was concerned, February-trained plots had higher primocane leaf $\mathrm{P}, \mathrm{K}, \mathrm{S}, \mathrm{B}, \mathrm{Cu}, \mathrm{Mn}$, and $\mathrm{Zn}$ than August-trained plots in 2013 (Table 4). A similar training-time effect was observed for primocane leaf $\mathrm{K}$ in 2014, whereas the opposite effect was found for leaf $\mathrm{Mg}$ and $\mathrm{Zn}$ (Table 5). In 2013, there was an irrigation $\times$ training time effect on primocane leaf $\mathrm{Ca}$ and $\mathrm{Mg}$ with February-trained plants having a higher concentration of both nutrients in the primocane leaves than the August-trained plants only when the plants were not irrigated after harvest (Table 4). August-trained plants had primocane leaves with leaf $\mathrm{K}$ and $\mathrm{B}$ concentrations below the sufficiency range in 2013.

Floricane leaf nutrient concentration. The treatments had variable effects on the nutrient concentrations in the floricanefruiting lateral leaves (Tables 6 and 7). The nutrients in these leaves often differed between cultivars or were affected by cultivar interactions. For example, 'Black Diamond' had greater floricane leaf $\mathrm{N}$ than 'Marion' in 2013, and greater leaf N, P, Ca, Mg, S, Fe, Cu (with postharvest irrigation only), $\mathrm{Mn}, \mathrm{Zn}$, and Al than 'Marion' in 2014.

Weed management effects on floricane leaf nutrient concentration were complicated by interactions with cultivar and irrigation. In both years, the presence of weeds in the nonweeded plots reduced floricane leaf $P$. Leaf $\mathrm{Zn}$ was higher in the weed mat plots than in the other weed management strategies in both years, whereas leaf $\mathrm{Al}$ was lower in the weed mat plots than the other two weed management treatments in 2014. In 2013, 'Black Diamond' had lower floricane leaf N in the nonweeded treatment than with weed control, whereas weed management strategy had no effect on floricane leaf $\mathrm{N}$ in 'Marion'. However, in 2014, both cultivars grown in nonweeded plots had a lower floricane leaf $\mathrm{N}$ than in weed mat plots. 'Black Diamond' had higher leaf Ca than 'Marion' when the weeds were controlled (Table 6)

Training affected floricane leaf nutrient concentrations directly only in 2014, when August-trained plants had higher floricane leaf $\mathrm{N}, \mathrm{P}, \mathrm{Ca}, \mathrm{Mg}, \mathrm{S}, \mathrm{B}$, and $\mathrm{Zn}$ than those trained in February. In 2013, August-trained 'Black Diamond' increased floricane leaf $\mathrm{Ca}$ compared with 'Marion', whereas there was no difference between cultivars when training in February. Training time only affected leaf Mn in 'Marion' plants that were irrigated postharvest, where February training resulted in higher Mn than August training $(P=0.031$; Fig. 3A). In 2014, 'Black Diamond' trained in August had a higher floricane leaf $\mathrm{Ca}, \mathrm{B}$, and $\mathrm{Zn}$ than when trained in February, whereas there was no effect in 'Marion'. In 2014, floricane leaf $\mathrm{Ca}$ was affected by a cultivar $\times$ irrigation $\times$ training interaction ( $P=0.0106$; Fig. 3B). In 'Marion', floricane leaf $\mathrm{Ca}$ was unaffected by irrigation or training time but was lower than in 'Black 


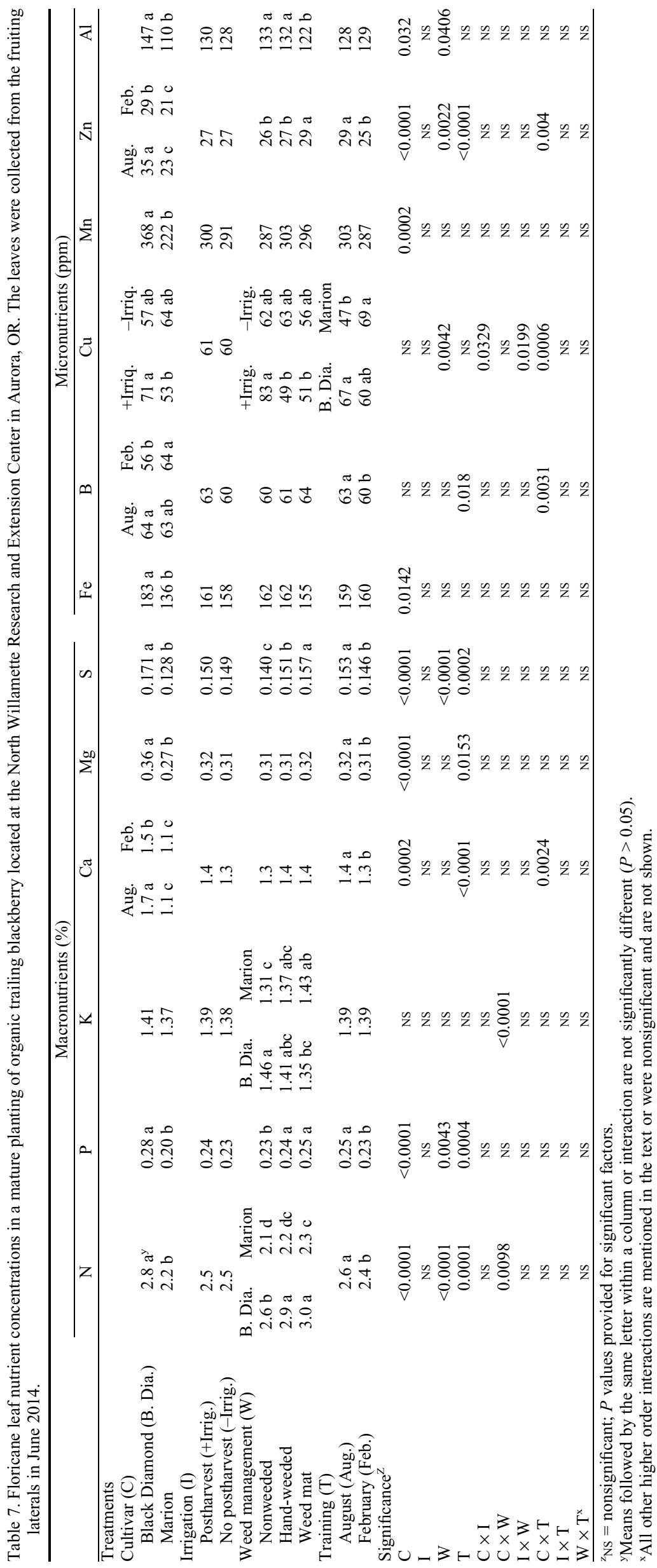

Diamond', whereas in 'Black Diamond', floricane leaf $\mathrm{Ca}$ was lowest in plants that received no postharvest irrigation and were February trained. Irrigation did not have a direct effect on any floricane leaf nutrient in either year.

Fruit nutrient concentration. The concentration of nutrients in the fruit was mostly affected by cultivar and weed management (Tables 8 and 9). For example, 'Black Diamond' had higher concentrations of many nutrients in the fruit than 'Marion', including N, P (in 2014 and only with August training), K, S, Fe (2013 only), B, Cu (August-trained plants only in 2014), Mn (in 2014 and with postharvest irrigation only), and Al. 'Marion', on the other hand, often had higher concentrations of $\mathrm{Ca}$ (August-trained plants only in 2013 and with weed mat only in 2014), Mn (in 2014 and only with postharvest irrigation or weed mat), and Zn (2013 and only in nonweeded) in the fruit than 'Black Diamond'.

The effects of weed management were varied. In some cases, plants grown with weed control produced fruit with higher concentrations of $\mathrm{N}$ (with weed mat in August-trained plants only in 2014), P (with weed mat only in 2014), K (2103 only; in 'Marion' only with weed mat), Mg (2013 only), S (only in 'Black Diamond' in 2013 and with weed mat only in 2014), Fe (2013 only), B (2013 only), Cu (only in 'Black Diamond' in 2013), Mn (only in 2014 in hand-weeded 'Marion'), and Zn (only 'Black Diamond' in 2013 and with weed mat only in 2014) than those in nonweeded plots. Sometimes plants grown with weed mat also had higher concentrations of fruit N (in 2014 only for February-trained plants), P, S (2014 only), and $\mathrm{Cu}$ (2014 only) than with handweeding but had lower concentrations of $\mathrm{Ca}$ ('Black Diamond' only in 2014) and Mn (only in 2013 when August trained).

Only a few nutrients in the fruit were affected directly by training time (Tables 8 and 9 ). August-trained plants had higher concentrations of Ca ('Marion' in 2013 only) and Mg ('Black Diamond' only in 2014). A significant three-way interaction among cultivar, irrigation, and training time in 2013 revealed that August-trained plants also had a higher concentration of $\mathrm{K}$ in the fruit than February-trained plants when 'Black Diamond' was irrigated after harvest ( $P=0.047$; Fig. 4).

Aluminum was the only nutrient in the fruit affected directly by postharvest irrigation (Table 8). In this case, the concentration of Al was greater with than without postharvest irrigation (2013 only).

\section{Discussion}

In Fall 2012, soil pH was 5.7, and the only nutrients below the recommended levels (Hart et al., 2006) were K and B (Harkins, 2013). Supplemental lime and B were broadcast in early 2013 , and $\mathrm{K}$ was applied by fertigation (Table 1). Soil $\mathrm{pH}$ increased to an average of 5.8 by Fall 2013, 

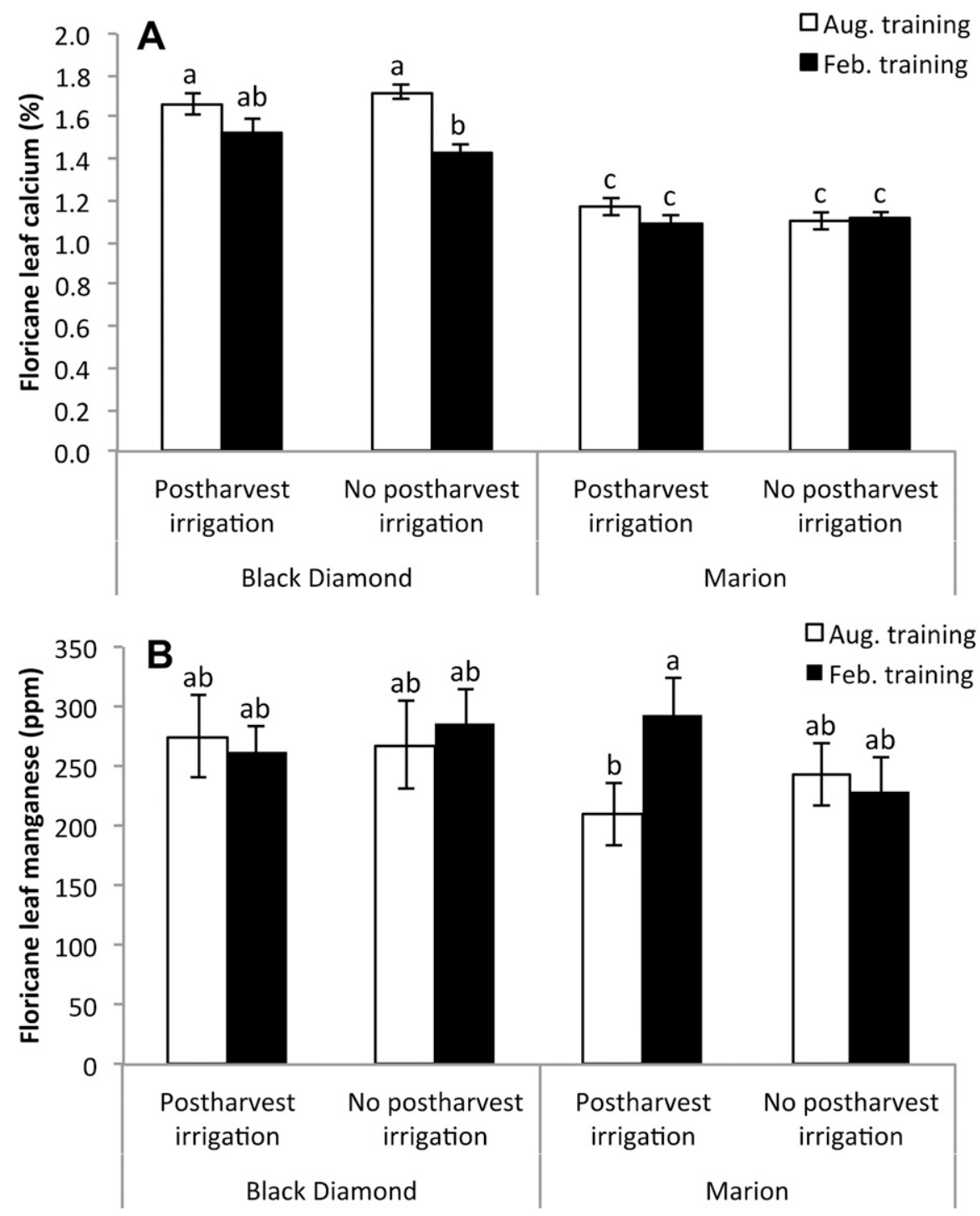

Fig. 3. Effects of irrigation strategy and training time on (A) floricane-fruiting lateral leaf calcium concentration in $2014(P=0.031)$ and $(\mathbf{B})$ floricane-fruiting lateral leaf manganese concentration in $2013(P=0.0106)$ in mature organic 'Black Diamond' and 'Marion' trailing blackberry grown at the North Willamette Research and Extension Center in Aurora, OR. Mean $\pm \mathrm{sE}$; means followed by the same letter within the interaction presented are not significantly different $(P>0.05)$.

but soil $\mathrm{B}$ and $\mathrm{K}$ were still low. Additional $\mathrm{B}$ and $\mathrm{K}$ fertilizer were applied in Spring 2014, which resulted in a slight increase in soil levels by Fall 2014. In blueberry (Vaccinium corymbosum L.), soil K also increased over time when plants were fertilized with fish emulsion (Larco et al., 2013). Primocane leaf B concentration was below the sufficiency range throughout the study, including during the establishment years (Harkins et al., 2014).

Soil $\mathrm{K}$ under weed mat was higher than the other weed management treatments, although still below the recommended threshold (Hart et al., 2006). Primocane leaf $\% \mathrm{~K}$ was also below the sufficiency range. Interestingly, 'Black Diamond' had higher floricane leaf $\% \mathrm{~K}$ in the nonweeded treatment than the weed mat treatment in 2014. However, it is not clear from these data if the nutrient content (as opposed to concentration) was actually different, and this effect was not observed during the establishment years (Harkins et al., 2014) or in 2013. Harkins et al. (2014) found that the amount of $\mathrm{K}$ removed from the field in fruit and floricane prunings during the first fruiting year ranged from 36 to $82 \mathrm{~kg} \cdot \mathrm{ha}^{-1}$, depending on the weed management treatment. If $\mathrm{K}$ removal was similar in the current study, it would have exceeded the amount of $\mathrm{K}$ that was applied (Table 1 ), implying that $\mathrm{K}$ would not be replenished in the soil at the rate it was being removed. Primocane leaf $\mathrm{K}$ concentrations were highest in 2012 (Harkins et al., 2014) and lowest in 2014, indicating that this may have indeed been taking place. Even though soil $\mathrm{K}$ increased over the study period, additional fertilizer K or use of another fertilizer source with a higher $\mathrm{K}$ content appeared necessary to provide enough $\mathrm{K}$ in this production system since soil and primocane leaf levels were consistently low.
Plant tissue nutrient concentrations did not appear to be consistently related to soil nutrient level across treatments. For instance, although soil $\mathrm{Ca}$ was highest under weed mat, $\mathrm{Ca}$ concentration was actually lower in plant tissues grown with weed mat than those with at least one of the other weed management treatments, including the fruit in 2013, floricane tissue sampled during caning out at the end of July in 2013 (Dixon, 2015), 'Black Diamond' floricane leaves and fruit in 2014, and primocane tissue from plants without postharvest irrigation sampled at the end of the year during the dormant period (Dixon, 2015). The only plant tissue grown with weed mat that had higher $\mathrm{Ca}$ than the nonweeded treatment was 'Marion' floricane leaves in 2014.

Soil Ca increased over the 3 years in the nonweeded and weed mat treatments and was higher under weed mat than the other weed management strategies. Soil $\mathrm{Mg}$ was higher with weed mat than with handweeding. Increases in these nutrients were likely because of the lime applied during the study period. Differences in soil $\mathrm{Ca}$ and $\mathrm{Mg}$ did not translate into similar patterns in primocane leaves, floricane leaves, or fruit. Fruit and floricane leaf concentrations of $\mathrm{Ca}$ and $\mathrm{Mg}$ tended to be slightly higher in 2014 than 2013, although this was not seen in primocane leaves.

The soil in the weed mat plots was drier during soil sampling than in the other weed management plots (E. Dixon, personal observation) and had a higher organic matter content, likely due to increased root growth over the study (Dixon et al., 2015). There may have been less leaching of soil cations in the drier treatments (i.e., no postharvest irrigation and weed mat). Lime and B were applied by broadcasting the products on top of the weed mat. Because of the weed management treatment response observed, it is clear that nutrients are able to pass through the weed mat to the soil with relative ease. Landscape fabrics have previously been shown to be permeable to organically derived $\mathrm{N}$ and $\mathrm{P}$ (Zibilske, 2010). Interestingly, although the soil $\mathrm{pH}$ increased from 2012 to 2014 in the weed mat treatment, the hand-weeded and nonweeded plots saw no change in soil $\mathrm{pH}$.

Primocane leaf nutrient analysis is an important tool used by growers to develop and modify nutrient management programs. The nutrient concentrations of primocane leaves sampled in late July to early August are compared with published standards (Hart et al., 2006) with the goal of improving the nutrient status of the subsequent floricanes (the following year) through fertilization in autumn or spring (Strik and Bryla, 2015). In our study, primocane leaf concentrations of $\mathrm{N}, \mathrm{K}, \mathrm{Ca}, \mathrm{Mg}$, and $\mathrm{B}$ were low or below the recommended sufficiency ranges in one or both years, similar to what Harkins et al. (2014) found during the establishment years, although in their case, $\mathrm{K}$ was sufficient in the planting. In the 4 years of primocane leaf 


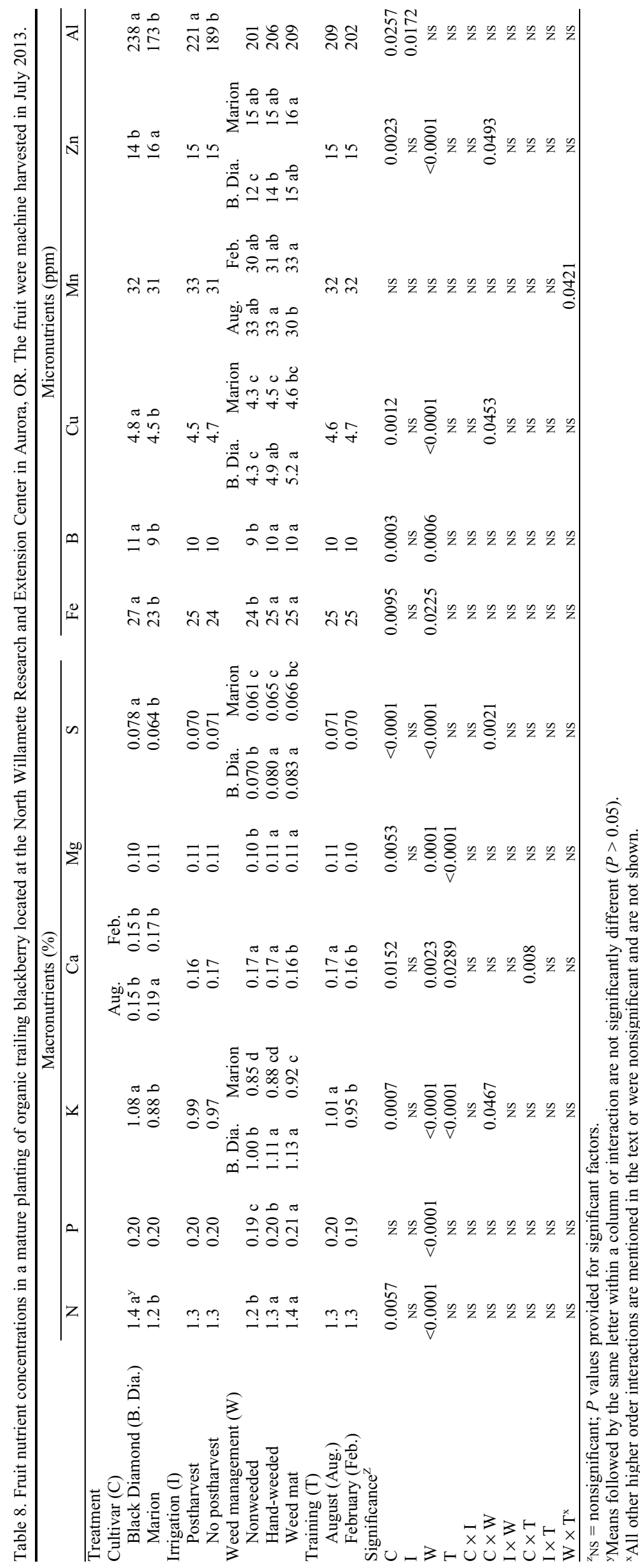

testing included in that study and the present one, 'Black Diamond' always had a lower leaf $\mathrm{N}$ than 'Marion' and was at the very bottom or below the sufficiency range, a response also observed by Fernandez-Salvador et al. (2015a). In another study, 'Black Diamond' had the lowest primocane leaf $\mathrm{N}$ among six cultivars tested, not including 'Marion' (Fernandez-Salvador et al., $2015 b$ ). It is unclear whether 'Black Diamond' requires less $\mathrm{N}$ than 'Marion' or if the $\mathrm{N}$ content of the plants was in balance relative to yield, with less $\mathrm{N}$ allocated to primocane leaves, but more to other plant parts such as fruit, floricane leaves, and floricane tissue (Dixon, 2015). 'Black Diamond' produced $2 \mathrm{t} \cdot \mathrm{ha}^{-1}$ more fruit than 'Marion' in 2012 (Harkins et al., 2013). In 2013 and 2014, the cultivars did not significantly differ in yield (Dixon et al., 2015). Although some of the primocane leaf nutrients were at the low end of the sufficiency range, or even below the range for some treatments, yield was generally in the expected range, except in nonweeded plots and in August-trained 'Marion' plants in 2014, which experienced cold damage (Dixon et al., 2015). It is possible that the two cultivars were allocating $\mathrm{N}$ differently, as 'Black Diamond' had a higher $\% \mathrm{~N}$ in floricane leaves and fruit during the first year of production (Harkins et al., 2014) and the following 2 years. 'Black Diamond' also had higher floricane $\% \mathrm{~N}$ and tended to have higher primocane $\% \mathrm{~N}$ than 'Marion' (Dixon, 2015). Nelson and Martin (1986) found that the rate of applied fertilizer $\mathrm{N}$ and $\mathrm{K}$ were better predictors of yield in 'Thornless Evergreen' blackberry than primocane leaf or soil nutrient concentrations, although they still considered primocane leaf nutrient samples as the best indicator for plant nutrient needs in the following year. Since the recommended nutrient standards were primarily developed using data from 'Marion' (Hart et al., 2006), it is possible that other cultivars are not well represented by these sufficiency ranges. Primocane tissues (cane and nonsenescent leaves) were also higher in 'Marion' for $\% \mathrm{P}$, whereas floricane tissues had a higher \%P in 'Black Diamond' (Dixon, 2015).

Leaves were not washed before analysis (a standard sampling practice, Hart et al., 2006), so nutrients such as $\mathrm{Fe}$ and $\mathrm{Al}$ may be highly variable because of soil contamination. Copper fungicide applied in Mar. and Apr. 2014 resulted in an order of magnitude increase of $\mathrm{Cu}$ in the 2014 floricane-fruiting lateral leaves compared with the prior year. Soil $\mathrm{Cu}$ levels were also almost doubled from 2013 to 2014. Despite increased soil and floricane leaf $\mathrm{Cu}$, primocane leaf $\mathrm{Cu}$ did not increase in 2014 and was again at the low end of the sufficiency range.

The cultivar by weed management interaction on floricane leaf $\% \mathrm{~N}$ suggested that 'Black Diamond' was less effective at competing with weeds for $\mathrm{N}$ than 'Marion'. In both years, there was a much larger reduction 


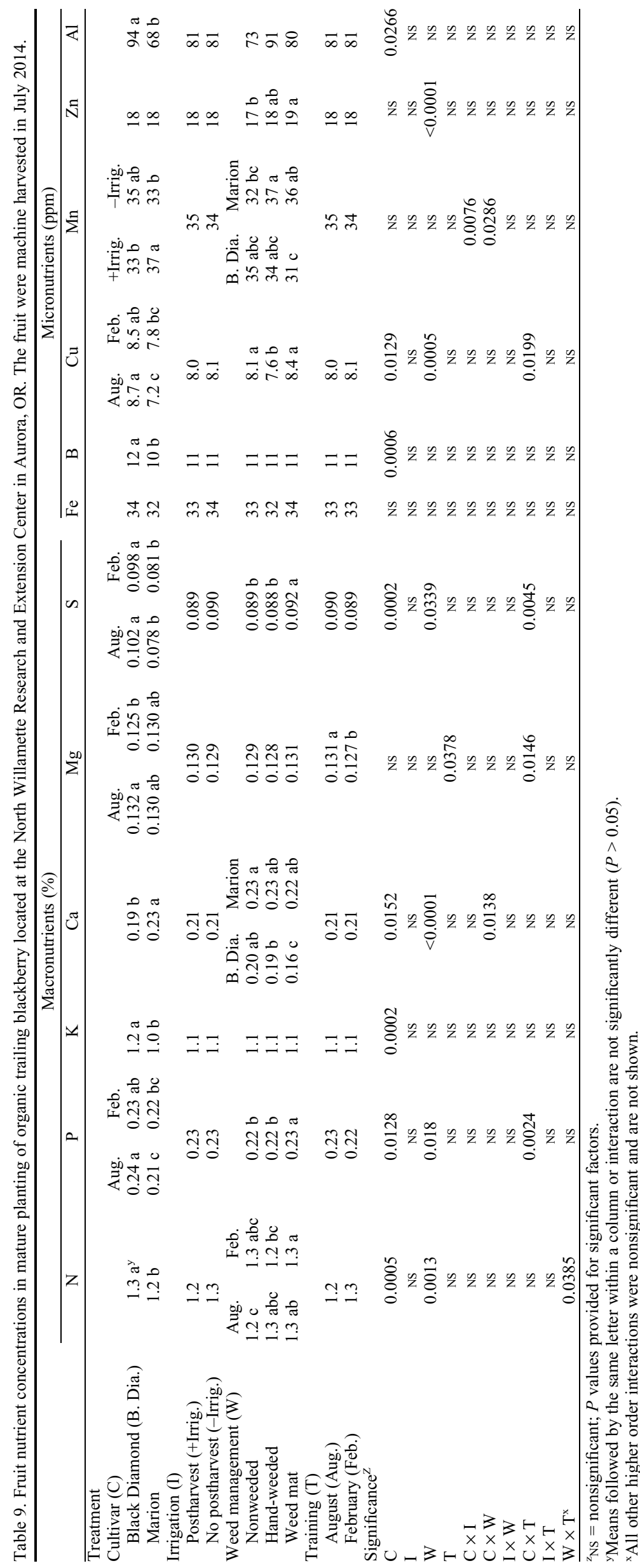

in floricane leaf $\% \mathrm{~N}$ when plants were grown without weed control in 'Black Diamond' than in 'Marion'. This cultivar response to weeds was consistent with the effects seen on yield (Dixon et al., 2015) in the mature planting, although there was no cultivar response to weed presence on leaf $\% \mathrm{~N}$ or yield during the establishment years (Harkins et al., 2014). Although 'Black Diamond' had a higher concentration of $\mathrm{N}$ in each part of the floricane than 'Marion', including in the leaves, canes (Dixon, 2015), and fruit, it had a lower concentration of $\mathrm{N}$ in the primocane leaves, which is consistent with what was reported by Harkins et al. (2014).

Training effects seen in 2014 on the nutrient concentration of floricane-fruiting lateral leaves were probably because of the treatment effects on winterhardiness documented by Dixon et al. (2015). Floricane leaves in 2014 had higher concentrations of most nutrients than they did in 2013, most likely because of the increase in fertilizer rate from $56 \mathrm{~kg} \cdot \mathrm{ha}^{-1}$ of $\mathrm{N}$ in 2012 (Harkins et al., 2013) to $90 \mathrm{~kg} \cdot \mathrm{ha}^{-1}$ of $\mathrm{N}$ in 2013; this also led to an increase in the other nutrients present in the organic fertilizers used (Table 1). Floricanes use primarily stored nutrients for new growth in the spring (those taken up when these canes were primocanes in the prior year), whereas primocane growth is supported by newly taken up nutrients (Malik et al., 1991; Mohadjer et al., 2001; Naraguma et al., 1999; Whitney, 1982). Therefore, the primocanes that grew in 2013 (and became floricanes in 2014) would have had access to the increased fertilizer application as compared with the primocanes that grew in 2012.

'Black Diamond' had a higher concentration of many nutrients in the fruit than 'Marion' in both years, despite producing larger fruit with a higher water content than 'Marion' (Dixon et al., 2015). Our results are similar to what was found by Harkins et al. (2014) in 2012. The only nutrient consistently higher in 'Marion' than 'Black Diamond' was $\mathrm{Ca}$, which is known to be important for good fruit quality and storage life in other species (Jones et al., 1983; Léchaudel et al., 2005; Simmons et al., 1998). Interestingly, 'Black Diamond' has been found to have firmer fruit than 'Marion' (Fernandez-Salvador et al., 2015a; Finn et al., 2005). It is possible that low Ca concentrations in 'Black Diamond' fruit still resulted in higher Ca content than 'Marion' considering 'Black Diamond' larger fruit weight and higher water content (Dixon et al., 2015) as $\mathrm{Ca}$ is mobile in the xylem (Jones et al., 1983). It is also possible that the compact growth habit (FernandezSalvador et al., 2015a; Finn et al., 2005; Harkins et al., 2013), and perhaps a lower leaf:fruit ratio, found in 'Black Diamond' was responsible for the higher fruit nutrients, although mango (Mangifera indica L.) had higher $\mathrm{Ca}$ with lower leaf:fruit ratios (Léchaudel et al., 2005; Simmons et al., 1998). Leaf:fruit ratio had no effect on the 


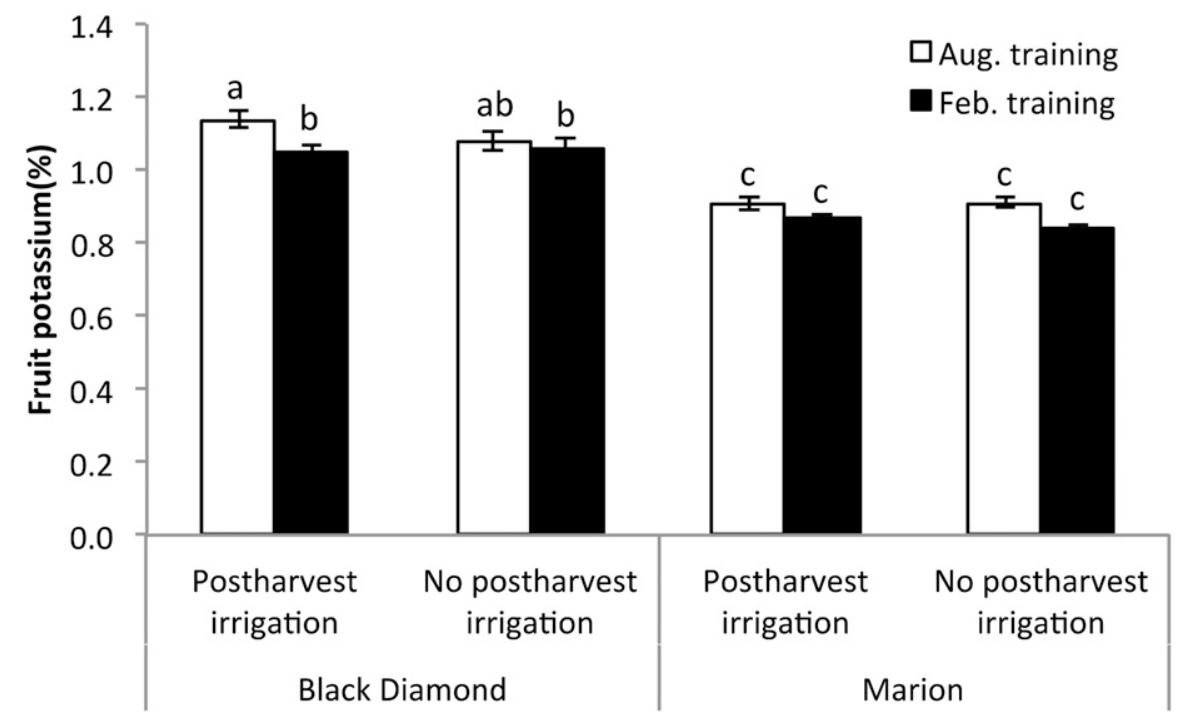

Fig. 4. Effects of irrigation strategy and training time on fruit potassium concentration in $2013(P=0.047)$ in mature organic 'Black Diamond' and 'Marion' trailing blackberry grown at the North Willamette Research and Extension Center in Aurora, OR. Mean $\pm \mathrm{SE}$; means followed by the same letter within the interaction presented are not significantly different $(P>0.05)$.

accumulation of cations in grape (Vitis vinifera L.) (Etchebarne et al., 2010).

\section{Conclusions}

Plant and soil nutrient levels were affected by the treatments studied. Although the cultivars had limited effects on soil nutrients, they differed in the concentration of many nutrients in the plant tissues studied. 'Black Diamond' had higher concentrations of some nutrients in floricane tissues than in primocane leaves, including $\mathrm{N}$ and $\mathrm{P}$. Since the sufficiency standards (Hart et al., 2006) were developed primarily with data from 'Marion', they may need to be adjusted for other cultivars, including Black Diamond. Withholding irrigation after harvest affected most soil nutrients, although effects on plant tissue nutrients were limited. Since the impact of postharvest irrigation on plant growth and yield were also limited after 3 years (Dixon et al., 2015), deficit irrigation seems to be an effective strategy for water conservation. Organic matter, $\mathrm{pH}, \mathrm{NH}_{4}-\mathrm{N}$, $\mathrm{K}, \mathrm{Ca}, \mathrm{Mg}, \mathrm{S}, \mathrm{Cu}, \mathrm{Mn}$, and $\mathrm{Zn}$ were all higher in soil under weed mat than in handweeded plots, as were nutrient concentrations in many plant parts. These results combined with the increased plant growth, yield, and profit (Dixon et al., 2015; Dixon and Strik, 2015; Harkins et al., 2013) gained from using weed mat rather than hand-weeding or no weeding indicate that weed mat is a very effective management tool in this organic system. The effects of primocane training time were variable. Training primocanes in August increased the concentration of some nutrients in the aboveground plant, but August training is not recommended in 'Marion' because of the greater risk of cold damage in winter (Dixon et al., 2015). Although our study provides information on the impact of
Fernandez-Salvador, J., B.C. Strik, Y. Zhao, and C.E. Finn. 2015b. Trailing blackberry genotypes differ in yield and postharvest fruit quality during establishment in an organic production system. HortScience 50: 240-246.

Finn, C.E., B.M. Yorgey, B.C. Strik, H.K. Hall, R.R. Martin, and M. Qian. 2005. 'Black Diamond' thornless trailing blackberry. HortScience 40: 2175-2178.

Gavlak, R.G., D.A. Horneck, and R.O. Miller. 1994. Soil and plant tissue reference methods for the western region. Univ. Alaska Western Reg. Publ. 125.

Harkins, R.H. 2013. Weed, water, and nutrient management practices for organic blackberry production. MS thesis, Ore. St. Univ., Corvallis, OR. 15 July 2013. < http://ir.library.oregonstate. edu/xmlui/bitstream/handle/1957/40102/ HarkinsReneeH2013.pdf? sequence $=1>$.

Harkins, R.H., B.C. Strik, and D.R. Bryla. 2013. Weed management practices for organic production of trailing blackberry: I. Plant growth and early fruit production. HortScience 48:1139-1144.

Harkins, R.H., B.C. Strik, and D.R. Bryla. 2014. Weed management practices for organic production of trailing blackberry: II. Accumulation and loss of biomass and nutrients. HortScience 49:35-43.

Hart, J., B. Strik, and H. Rempel. 2006. Caneberries. Nutrient management guide. Ore. State Univ. Ext. Serv., EM8903-E, Corvallis, OR.

above organic production systems on ther study is needed to assess treatment effects on blackberry crowns and roots as they comprise a significant portion of the plant and root and crown storage could impact nutrient concentrations in aboveground plant parts.

\section{Literature Cited}

Bell, N., E. Nelson, B. Strik, and L. Martin. 1992. Assessment of winter injury to berry crops in Oregon, 1991. Agr. Expt. Sta. Spec. Rpt. 902, Oregon State Univ.

Bell, N.C., B.C. Strik, and L.W. Martin. 1995. Effect of primocane suppression date on 'Marion' trailing blackberry. I. Yield components. J. Amer. Soc. Hort. Sci. 120:21-24.

Dahnke, W.C. 1990. Testing soils for available nitrogen, p. 120-140. In: R.L. Westerman (ed.). Soil testing and plant analysis. Soil Sci. Soc. Amer. Book Series 3. SSSA, Madison, WI.

Dixon, E.K. 2015. Weed management, training, and irrigation practices for organic production of trailing blackberry: Plant growth, yield, and nutrients. MS thesis, Ore. St. Univ., Corvallis, OR. 15 Oct. 2015. < http://ir.library.oregonstate. edu/xmlui/handle/1957/57654>.

Dixon, E.K. and B.C. Strik. 2015. Weed control increases growth, cumulative yield, and economic returns of machine-harvested organic trailing blackberry. Acta Hort. In press.

Dixon, E.K., B.C. Strik, L.R. Valenzuela-Estrada, and D.R. Bryla. 2015. Weed management, training, and irrigation practices for organic production of trailing blackberry: I. Mature plant growth and fruit production. HortScience 50:1165-1177.

Etchebarne, F., H. Ojeda, and J.J. Hunter. 2010. Leaf:fruit ratio and vine water status effects on Grenache Noir (Vitis vinifera L.) berry composition: Water, sugar, organic acids and cations. S. Afr. J. Enol. Viticult. 31:106-115.

Fernandez-Salvador, J., B.C. Strik, and D.R. Bryla. 2015a. Liquid corn and fish fertilizers are good options for fertigation in blackberry cultivars grown in an organic production system. HortScience 50:225-233.
Jones, H.G., K.H. Higgs, and T.J. Samuelson. 1983. Calcium uptake by developing apple fruits. I. Seasonal changes in calcium content of fruits. J. Hort. Sci. 58:173-182.

Kuepper, G.L., H. Born, and J. Bachmann. 2003. Organic culture of bramble fruits. Horticultural production guide. Appropriate Technol. Transfer Rural Areas, IP022, Butte, MT. 15 Apr. 2015. $<$ https://attra.ncat.org/attra-pub/summaries/ summary.php?pub=15>.

Larco, H., B.C. Strik, D.R. Bryla, and D.M. Sullivan. 2013. Mulch and fertilizer management practices for organic production of highbush blueberry. II. Impact on plant and soil nutrients during establishment. HortScience 48:1484 1495.

Léchaudel, M., J. Joas, Y. Caro, M. Génard, and M. Jannoyer. 2005. Leaf:fruit ratio and irrigation supply affect seasonal changes in minerals, organic acids and sugars of mango fruit. J. Sci. Food Agr. 85:251-260.

Makus, D.J. 2011. Use of synthetic ground covers to control weeds in blackberries. Intl. J. Fruit Sci. 11:286-298.

Malik, H., D.D. Archbold, and C.T. MacKown. 1991. Nitrogen partitioning by 'Chester Thornless' blackberry in pot culture. HortScience 26:1492-1494. p. 199-223. In: A.L. Page (ed.). Methods of soil analysis, Part 2. Agronomy monograph 9. 2nd ed. ASA and SSSA, Madison, WI.

Mehlich, A. 1984. Mehlich-3 soil test extractant: A modification of Mehlich-2 extractant. Commun. Soil Sci. Plant Anal. 15:1409-1416.

Meyers, S.L., K.M. Jennings, D.W. Monks, and W.E. Mitchem. 2014. Effect of weed-free strip width on newly established 'Navaho' blackberry growth, yield, and fruit quality. Weed Technol. 28:426-431.

Mohadjer, P., B.C. Strik, B.J. Zebarth, and T.L. Righetti. 2001. Nitrogen uptake, partitioning and remobilization in 'Kotata' blackberry in alternate-year production. J. Hort. Sci. Biotechnol. 76:700-708.
McLean, E.O. 1982. Soil pH and lime requirement, 
Naraguma, J., J.R. Clark, R.J. Norman, and R.W. McNew. 1999. Nitrogen uptake and allocation by field-grown 'Arapaho' thornless blackberry. J. Plant Nutr. 22:753-768.

Nelson, E. and L.W. Martin. 1986. The relationship of soil-applied $\mathrm{N}$ and $\mathrm{K}$ to yield and quality of 'Thornless Evergreen' blackberry. HortScience 21:1153-1154.

Nelson, D.W. and L.E. Sommers. 1996. Total carbon, organic carbon and organic matter, p. 961-1010. In: J.M. Bartels (ed.). Methods of soil analysis: Part 3: Chemical methods. 3rd ed. ASA and SSSA Book Series 5, Madison, WI.
Simmons, S.L., P.J. Hofman, A.W. Whiley, and S.E. Hetherington. 1998. Effects of leaf:fruit ratios on fruit growth, mineral concentration and quality of mango (Mangifera indica L. cv. Kensington Pride). J. Hort. Sci. Biotechnol. 73:367-374.

Strik, B.C. and D.R. Bryla. 2015. Uptake and partitioning of nutrients in blackberry and raspberry and evaluating plant nutrient status for accurate assessment of fertilizer requirements. HortTechnology 25:452-459.

Strik, B.C. and C.E. Finn. 2012. Blackberry production systems - a worldwide perspective. Acta Hort. 946:341-348.
U.S. Department of Agriculture. 2014. Table 33: Berries: 2012 and 2007. In: 2012 Census of Agriculture. U.S. Dept. Agr., Natl. Agr. Statistical Serv., Washington, DC.

U.S. Department of the Interior. 2013. U.S. Department of the Interior, Bureau of Reclamation, AgriMet. Boise, ID. 5 Apr. 2015. <http:// www.usbr.gov/pn>.

Whitney, G.G. 1982. The productivity and carbohydrate economy of a developing stand of Rubus idaeus. Can. J. Bot. 60:2697-2703.

Zibilske, L.M. 2010. Permeability of fabric ground covers to organically-derived nutrients. Intl. J. Fruit Sci. 10:109-122. 